\title{
An Innovation Civilization in the Context of the Anthroposphere Crisis of the Technogenic Society
}

\author{
Evgeny G. Kamensky ${ }^{1} \&$ Evgeny I. Boev ${ }^{1}$ \\ ${ }^{1}$ Southwest State University (SWSU), Kursk city, Russian Federation \\ Correspondence: Evgeny I. Boev, Department of Philosophy and Sociology, Faculty of Economics and \\ Management, Southwest State University (SWSU), 94, 50 Let Oktyabrya St., 305040, Kursk city, Russian \\ Federation. Tel: 74-7-1252-3826. E-mail: evgeny-kursk@rambler.ru
}

\author{
Received: October 18, 2014 Accepted: November 28, 2014 Online Published: January 14, 2015 \\ doi:10.5539/ass.v11n4p328 URL: http://dx.doi.org/10.5539/ass.v11n4p328
}

\begin{abstract}
The article presents the philosophical and methodological model of the anthropological crisis caused by social and cultural transformation of the modern civilization. It analyses the essence and cause of the anomie and social orienting cultural regulatory mechanisms in the social system. The authors consider existential characteristics of the individual in the new "innovative" social space and specify transformation vectors of the innovative civilization. The study suggests that the innovative civilization should be considered as a stage of social development and a type of social organization, based on the achievements of the technological civilization, however, it is filled with new socio-humanistic contents. The results obtained will serve as a theoretical and methodological basis for further fundamental studies of possible risks, threats and prospects in the development of the innovative civilization.
\end{abstract}

Keywords: anomie of the social system, development scenarios of the technogenic society, existential risks, the anthropological crisis, the innovative civilization

\section{Introduction}

The Modern society is in the crisis, which can be measured by extremely different criteria such as essentially-content typologies and external system and structural features. Anyway, the ontology of social and cultural space is described and explained as a crisis anthroposphere. There exists an aggravation of global crises, so the humankind needs to change the strategy of development. Many historians, philosophers, sociologists share the idea that a turning point in the history of civilization development is coming (Beck, 1992a; Beck, 1992b; Beck, 1999; Beck, Giddens, \& Lash, 1994; Behmann, 2010; Moiseev, 1998; Sorokin, 1964; Stepin, 2003; Stepin, 2005; Stepin, 2007; Toffler, 1980, et al.). For example, V. S. Stepin (2003, p. 5) argues on the turn of the century as a time of soul-searching, a time to search new ways of civilized development. In this connection, one of the key factors that determine the shape and tendencies of the modern civilization development is the intensification of innovation activity in a wide range of technologies, products and services. In this situation rethinking of the complex social problems is required, i.e. management effectiveness, safety, ways out of the crisis, redress, transformation of "human nature" in the emerging anthropo-coordinate technoculture. "Retiring into oneself," contemplation, the decision of any internal problems, "consideration" of anything and any other forms of psychological activity are certainly relevant in the existential aspect of the understanding of human subjectivity, its reflexive activity, transcendence and transcendentality (the understanding of the terms from I. Kant (1998) to E. Husserl (1970; 1995), especially by M. Heidegger (1967).

The novelty of this research is to review a prognostic perspective of innovation in the context of modern civilization and socio-humanitarian axiological crisis.

\section{Research Methodology}

Scientists have been discussing the source of the crisis for a long time. They think that it goes far beyond the scientific analysis because it is becoming transdisciplinary. Numerous opponents and defenders of various positions use theological interpretations, the ordinary consciousness, speculative sciences in their argument, at that alternately change their opinions. This, however, may be due to different reasons and is not discussed in this paper. Anyway, it is necessary to present the problem, based on the three pillars of scientific analysis: objectivity, 
systematization and historicism. Unnecessary metaphorical statements, inappropriate integration of the forms of knowledge, which have not been integrated yet, and indulging the desire to cover the problem in its entirety and complexity should be avoided.

An integrated approach based on an understanding of synergetics as an interdisciplinary direction of postnonclassical science (in the terminology of V. S. Stepin) is required to solve the problem. This approach will form one of the integrating beginnings to construct and manage sustainable development processes in the global crisis today.

\section{Results and Discussion}

\subsection{Anthropological Dimension of the Current Crisis}

First, let us try to understand what is the essence of the crisis in general and of the current crisis, in particular. What does its anthropological dimension contain? We would like to make a reservation, however, that the purity of certain concepts in the presented paper can be criticized, because they have different interpretations in philosophy, psychology and sociology. Therefore, it requires a need for a transdisciplinary synthesis within sociology. In any case, the authors will follow these principles in the present paper.

So, what is a crisis? Moreover, what is the crisis of the civilization, i.e. the anthropological one? Here we deal with at least three objective vectors of understanding without taking into account the most important ones. They are those connections that integrate these objects into the problem. We will try to explain its essence.

V. S. Stepin (2003, pp. 5-6), clarifying the problem of differences in the types of the civilization organization in the ontogeny of humanity, identifies two major types of civilisation. They are a traditional one and a type of civilization, which is often called the Western by the region of its origin. The latter is not represented only by Western countries now. He calls this civilization technological, as a crucial role in its development plays a constant search for new technologies, not only industrial ones for the economic growth, but also the technologies of social control and communication.

In fact, discussions about the terminology are not as important in this case because the concepts technological can be identified with Western, since they have similar characteristics. This is especially true if you take into account the processes of globalization that directly affect problems of civilization development and the formation of new types of historical process in the framework of other approaches.

In particular, M. S. Sharipov (2010, p. 120) notes that the world civilization is under intense pressure of Western values, its economy, technology and culture; and it is initiated by Western spirituality. The West invades achievements of globalization and exploits resources of neighboring countries for their own worldwide expansion. It sets forms of a new world order, causing major crises and deadlocks in underdeveloped countries. In his view, the international community will develop spontaneously obeying general the globalization projects; it will move to a single financial and economic, military, political and informational space, functioning exclusively on the basis of high technologies. Consequently, the crisis can be defined as a state of transition from one qualitative state to another, regardless of its axiological or other characteristics assigned to the process.

In addition, the society and civilization as complex phenomena of the social and cultural development have all the features of an integrated system. They are extremely complex, which requires consideration of a large number of parameters to assess their state. The authors of the paper share opinions of well-known experts in the field of synergetics (Budanov, 2009; Chernavsky, 2004; Haken, 2012; Kapitsa, Kurdyumov, \& Malinetsky, 2003; Mainzer, 2007; Stepin, 2005) with respect to the decisive role of the so-called order parameters in changing conditions of the system, this problem has not been adequately explained in social and humanitarian sciences.

V. S. Stepin (2007, p. 65) as the main type of system objects identifies simple (small) systems, complex (large) self-correcting systems and complex self-developing systems. In his opinion, each of these systems requires special categorical meanings for its development. Sharing this methodological view, we note that there are some attempts to formulate universal categories of describing the state of the crisis in the social system.

A concept of "social anomie" is widely used in sociology. Scientific periodicals interpret a great number of similar opinions the dynamics of views on the problem. However, they all criticize qualitative state of the modern social and cultural environment, its value-normative space. This concerns anomic of socio-orienting and cultural-regulatory mechanisms of the social system.

This is primarily a consequence of the state of anomie as the transition of the society and individual from one reference system of valuable normative regulation of the social life to another, which is qualitatively different from the previous one. This phase of transition is characterized by the absence of a clearly identifiable values 
and norms of the whole variety of social practices, at least according to the declared priorities in the society. These mechanisms are a complex of ideas, which are not secured by real mechanisms to support, but generate the variety of values and simulation practices of the normative regulation.

This understanding of anomie by E. Durkheim (1951), is a "normlessness" state. It is the space of forming different kinds of the anomie described by R. Merton (1938). According to R. Merton, the anomie characterizes a system of values and norms in the society, when achieving the legitimate aims by legitimate means is impossible. Under such conditions, the subjects of interaction find alternative adaptive models of social existence.

The authors consider the interpretations of the concept "anomie" by R. Merton and E. Durkheim to be complementarity. And, if the first focuses on the transitive periods in the development of the society, the second one focuses on the stages of relatively stable operation. Both concepts describe and explain socio-normative aspects of the behavior regulation. They are closely associated with the mechanism of the deviant behavior. The anomie serves as one of the essential prerequisites and the basic for developing a deviant behavior. New realities require new content of anthroposphere.

We believe that a particularly important methodological imperative of the modern understanding of "new human" existence should be a clear understanding of the non-classical crisis of rationality of technological civilizationIt should also be a postnonclassical methodology based on the reference of human values, principles of the ethics and interpretation of the canons of utility in the antropo-sotcio-cultural space.

The above construct allows us to remove restrictions of disciplinary matrices and consider philosophical and anthropological knowledge on trans-scientific grounds, representing the old problems of metaphysics (the soul, the inner world and the like) which were rejected by the materialist worldview. These problems are especially actual today. In addition, epistemological models of this kind look quite adapted to the social practice as a contextual environment of the personal formation.

\subsection{Conflict of Self-identity in the "Risk Society"}

In the context of growing globalization, a question about the features of the existence formation of the individual in the new "innovative" social space raises naturally. We are witnesses of a new personality formation, i.e. a global, post-industrial, informational one. At the same time aggravation of the conflict of self-identity in civilizational and global dimensions continues. Fast technical and technological progress rhythms do not coincide with natural human ones. Technical, cultural, political and economic innovations have accelerated the tempo of social time, making its stage several times shorter than physical, bio-physiological and social tempo of human development. If "human-machinery" relations do not fit into the cultural and social context of human relationships, then introduction of technical and technological innovations lead to devastating consequences, as in the case of violence against human principles of the progress, its humanitarian aspects.

Consequently, the state of modern technological civilization is described by the broad concept of "post-industrial". Currently, however, production and using technology continues to be an indicator of the formation of a new type of the society, and even globalization itself largely acquires a technological shade. Today, the technology has spread both the in the material and spiritual spheres. As a result, possession of advanced technology is becoming an indicator of a successful strategy for the social and economic development.

Discussing today's economic strategy, it is necessary to realize that the modern world is the world of technology, where people buy and sell the products of intellectual labor. We can say that the technological effectiveness has become a criterion of conformity for "modernity". On the background of accelerating technological globalization, the economic development is slowing down and there is a possibility of replacement the "industrialized" consciousness for "post-industrialized". But what are the characteristics of this type of consciousness and its ontological environment? In fact, in the modern world the so-called "innovation" paradigm of social development has its technical and technological base of the exponential update the world and human, where the latter demonstrates, at least, the basic provisions of transhumanism. It is clear that scientific and technological progress, giving new opportunities and perspectives for a person generates new risks and threats at the same time.

Therefore, a modern high-tech society is characterized as "Risk Society". Well-known sociologists and futurists of our time study this phenomenon: U. Beck (1999), D. Bell (1973), G. Behmann (2010), A. Giddens \& S. Lash (1994), N. Luhmann (1993), O. N. Yanitsky (2003). In other words, in today's global information and cultural space, the technological progress generates existential risks associated with deep existential problems of a person.

Today the globalization processes by themselves are making significant corrections to the formation of the 
personality, as it is becoming much more difficult for a person to relate himself with the development of events. Rapidly changing socio-cultural and anthropotechnical environment determines the changes in person's views on the essence of the human being, his outlook.

A. Toffler (1970) introduced the term "Future Shock" to characterize the current state of a human being. People get into a situation of shock, in a situation of stress, because they cannot adapt to objective changes with the necessary speed. That is why in the present conditions an internal, existential personal conflict arises with particular urgency. A. Toffler (1980, p. 13) in his book "The Third Wave" makes the assumption, that " $<\ldots>$ we are the final generation of an old civilization and, the first generation of a new one, and that much of our personal confusion, anguish, and disorientation can be traced directly to the conflict within us, and within our political institutions, between the dying Second Wave civilization and the emergent Third Wave civilization that is thundering in to take its place".

Speaking about the "Risk Society", it is impossible to ignore the works of U. Beck (1987; 1992a; 1992b; 1999), who proposed, in fact, such a detailed understanding of it for the first time. He asked: "Aren't risks at least as old as industrial society, possibly even as old as the human race itself? Isn't all life subject to the risk of death? Aren't and weren't all societies in all epochs 'risk societies"' (Beck, 1992a, p. 97).

The answer given by U. Beck (1992a, p. 98), is, in our opinion, fundamental to further consideration of "Risk Society". In his understanding, modern upheavals are not based on the decisions in favor of techno-economic advantages and new features based on the interpretation of hazards just as the cost of the progress. Risks are, in his opinion, involve industrial, that is techno-economic decisions and evaluation of utility.

Evaluation of utility plays a key role here. It is a prerequisite of expediency, directly determines the socio-political demand for innovation, as well as their economic evaluation. It is worth remembering a simple formula, according to which an innovation is recognized if it is socially and economically useful. Therefore, such innovation is justified and has a general socio-political opportunistic nature as it is quoted above.

On of we are discussing the problem in the political aspect quite deliberately, especially because, firstly, the course on the innovative development of the economy is officially political.

Secondly, it is simply impossible to realize this course without the participation of the institutions of public administration.

And, thirdly, in the words of U. Beck (1992a, p. 99) the consequences, affecting only a particular individual, became "risky cases". They systematically manifested, were statistically described, and in this sense became "predictable" types of events that could be subdued by supra-political rules of recognition, compensation and prevention. In this case, it is a natural for the socio-political institution to normalize typical forms of social relations as soon as they expand and become typical.

In addition, we can say that a "Risk Society" has always existed in a broad sense, as some risks always present in human life and society. In the described case U. Beck talks about a specific type of the society such as a "Risk Society", which can be characterized as the current state of the society, as a result of industrialization and as a context of formation a "Future Society". Moreover, the risks in U. Beck's understanding (1992a, p. 99) are a feature of modern society. They attract more attention of a wide range of scientific disciplines and moralists as an object of scientific analysis, because their calculation of risks is a kind of example of ethics without morality, mathematical ethics of the technological age.

\subsection{The Existential Risks of the Innovative Paradigm of Development for the Social System}

It is important not only to describe the current state of "social" as "Risk Society". It is necessary try to look inside the problem and realize why the "Risk Society" has been characterized like that. In this case, it is necessary to pay attention to the so-called existential risks of the innovative paradigm of development for the social system. Despite the fact that this question will require to find some support in the philosophical methodology of existentialism and phenomenology, which are complex and difficult for identification. The problem is necessary to be solved. It is necessary for because it is a man who is the main subject of consumption of the states like "futuristic chimeras of the Third Wave" (in the terminology of A. Toffler). A. Toffler (1980, p. 4) writes: "To begin with, many of today's changes are not independent of one another. Nor are they random. For example, the crack-up of the nuclear family, the global energy crisis $<\ldots>$, may all seem like isolated events. Yet precisely the reverse is true. These and many other seemingly unrelated events or trends are niter-connected. They are, in fact, parts of a much larger phenomenon: the death of industrialism and the rise of a new civilization".

It would be logical to understand just "Innovative Society" under the concept of a new civilization. "Risk 
Society" as the current state can be regarded as a transition to a new stage. In this case A. Toffler's (1980) and U. Beck's (1992a) have similar views. They are somewhat different only in the fact that the first is based on the best-case scenario, saying an existential confusion in anticipation of "the Third Wave". The second concentrates on the agony of the industrial wave, describing a contextual start of the "Risk Society". As a result, both heralded the end of industrialism and the occurrence of a certain stage of radical renewal of the societal system and its inevitability. As a result, both herald about the end of industrialism and the occurrence of a certain stage of radical renewal of the societal system and its inevitability. They can be a source of different variants of the innovation scenario. Like the fear of death, which introduces a man in a stupor or activate all the hidden reserves in order to be saved?

A. Toffler (1980, p. 4) writes: "So profoundly revolutionary is this new civilization that it challenges all our old assumptions. Old ways of thinking, old formulas, dogmas, and ideologies, no matter how cherished or how useful hi the past, no longer fit the facts. The world that is fast emerging from the clash of new values and technologies, new geopolitical relationships, new lifestyles and modes of communication, demands wholly new ideas and analogies, classifications and concepts. We cannot cram the embryonic world of tomorrow into yesterday's conventional cubbyholes. Nor are the orthodox attitudes or moods appropriate".

All this dictates the necessity of the deep social reconstruction in the institutional system. Nevertheless, the important thing is that you need a new world look. U. Beck (1992a, p. 101) says that there is not a single institution-not even in the plan-which would be ready for the "worst imaginable disaster", and there is no form of social order that would ensure social and political guarantees in the worst possible case. However, there are a lot of those who want to specialize in a particular area, i.e. to deny these threats. The care of the consequences that could guarantee a reduction of potential hazards is replaced with the dogma of technological infallibility, which is refuted by every next disaster.

Our modern society is full of technical risks for human beings. Their effects are not projected properly. The public institutional structures, which are responsible for the safety, are not able to prevent and probably adequately predict risks.

In this case, it would be logical to assume that the risk society has also other, equally important, dimension, which is a consequence of anthropo-technical area of risk, its product. This is the existential space of the risk society, the structures of the self and a personal self-realization space of a human being. This aspect is so difficult to define by scientific methods of cognition that we can only rely on intuition and philosophical multi-paradigmatics when making some shape to this area of social and cultural space.

\section{4 "Innovative Civilization" as a Scenario of the Technogenic Society}

"Innovative civilization" is relatively new, largely opportunistic term. However, its content, nevertheless, is quite capacious against the problem of this paper. Taking into account the fact that the concept "innovation" has become a part of everyday life, of its political and scientific dialogues, it is necessary to understand the concept differently in comparison with a traditional understanding.

If earlier in the context of the ideology of technological civilization "innovation" was understood as the technical-technological innovation, and their production reflected the ontological meaning of the civilized type of the society, then today, on the background of prevailing views related to its crisis, and understanding of the actual content of "innovation" is quite different. Primarily because of the meaning of development, typical for the technological civilization in its heyday, they become a tool for achieving certain, as written above, but not clear humanitarian aims of the human progress. In particular, the traditional abbreviation "NBIC" (NANO-BIO-INFO-COGNO) is still not completed and looks like a "NBICS", where "S" (SOCIO) refers to the inclusion into the convergence of social technologies. The latter, as well as opportunistic problematics of modern researches require a very careful studying in a variety of aspects. However, we shall only state the fact.

On these grounds with the development of social technologies in modern researches is complemented by the wave theory of N. D. Kondratyev (1998), which is future oriented. Consequently, in this case it is necessary to define more or less clear and categorical ontological outlines of the innovative civilization, to identify what researchers mean discussing this construct.

In particular, E. E. Sklyarova (2011) analyzed positions of such authoritative researchers as: A. Toffler (1970; 1980), N. N. Moiseev (1998), D. Bell (1973), P. Sorokin (1964) and others on this phenomenon considers the innovative civilization of to be the first stage of the post-industrial world, which marks the birth of "the Third Wave" (as interpreted by A. Toffler); and the technogenic civilization in all possible understandings is interpreted as its historical background. 
E. A. Drugova (2013, p. 41), referring to the problem of understanding the processes of formation of the innovative civilization, notes that a new type of civilization is sometimes referred to as "anthropogenic", emphasizing the care of technocratic attitudes to the ones of anthropological nature. Also in scientific literature, a new type of civilization called an information technology or post-industrial society. The crisis of twchnogenic civilization at the same time does not mean that a person becomes independent on technology, economics and objectively existing social relations. We also agree with E. A. Drugova that the problems of human-caused of technological changes, ethical problems of scientific and technological progress and a number of other humanitarian problems should take some shape and find its place in the framework of an innovative approach.

Moreover, the innovative civilization should be based on the integration of relatively autonomous social institutions of science, education, economy and industry within the objectives of the humanitarian paradigm of social development. Thus E. A. An (2012, p. 115) points to the unifying principle, which gives the obvious and clear effect. It is not because on the "combination of forces", summing up the economic potential of the previously autonomous participants in the reproduction process, but rather because of the synergistic effect resulting from a new quality of cooperation. Nevertheless, potential ethical problems of the innovation civilization are quite organically fitted in its humanistic paradigm but are quite keenly discussed (Sinetskiy, 2012).

Thus, in a situation of accelerated evolution of human civilization suffers from a total uncertainty of the future, "a fear of the future" scientific predictions are destroyed by "the cumulative effects of innovation", that make the society unstable. There is practically no way of the desired future development and a comprehensive transdisciplinary expertise of innovative projects has not been carried out. Many innovative strategies and programmes remain unfulfilled without the agreement of anthropological and sociological dimensions of the modern civilization.

\section{Conclusions}

Transformation of the modern civilization into the innovation defines an objective need for profound qualitative changes of all spheres of public life, and above all of innovation-oriented social and technological systems. The introduction of innovations suggests a positive qualitative change in certain social institutions as structural elements of the social system or the society as a whole. The social and cultural aspect of understanding innovations largely extends the scope of application as the result of the creative activity of new knowledge or inventions that are no longer correlated only with some positive economic effect, which was previously allocated as the main result of innovations.

The innovation strategy of civilization development implies a willingness not only to technological transformations, but also to the changes of moral values. That is why new forms of social practice will inevitably require some legitimation of moral values.

Consequently, innovative civilization is a stage of social development and a type of social organization based on the achievements of technogenic civilization, but filled with a new socio-humanitarian content, which has the following characteristics:

1) development of bio-and other variations of "living" practical ethics;

2) increase of a number of oriented to the anthropocentric paradigm social technologies which stimulate development of the individual potential;

3) actualization of the ethos of science to problem-oriented nature;

4) prediction of technical and technological and other anthropotechnic risks, scenarios of social development which are consciously formed by the humanity;

5) integration of transhumanism and environmental approaches;

6) development of innovation as a branch of knowledge, which conceptualize both the practice of innovation and the essence of innovation development, its ontology and axiology.

\section{Acknowledgements}

This research was supported by research grant of Russian Foundation for Humanities (RFH), project No 13-33-01023.

\section{References}

An, E. A. (2013). Integratsiya nauki, obrazovaniya i proizvodstva-bazis innovatsionnogo razvitiya i konkurentosposobnosti regiona. Agroprodovol'stvennaya politika Rossii, 5(17), 114-119. 
Beck, U. (1987). The Anthropological Shock and the Contours of the Risk Society. Berkeley Journal of Sociology, 22, 153-165.

Beck, U. (1992a). From Industrial Society to the Risk Society: Questions of Survival, Social Structure and Ecological Enlightenment. Theory, Culture and Society, 9(1), 97-123. http://dx.doi.org/10.1177/02632769 2009001006

Beck, U. (1992b). Risk Society. Towards a New Modernity (p. 260). London: Sage Publications Ltd.

Beck, U. (1999). World Risk Society. Cambridge: Polity Press.

Beck, U., Giddens, A., \& Lash, S. (1994). Reflexive modernization. Politics, Tradition and Aesthetics in the Modern Social Order. Stanford, CA: Stanford University Press.

Behmann, G. (2010). Moderne Gesellschaft: Risikogesellschaft, Informationsgesellschaft, Wissensgesellschaft (p. 248). Moskau: Logos.

Bell, D (1973). The Coming of Post-industrial Society: A Venture of Social Forecasting. New York, N.Y.: Basic Books.

Budanov, V. G. (2009). Metodologiya sinergetiki v postneklassicheskoi nauke i v obrazovanii: Monograph (p. 239). Moscow: URSS.

Chernavsky, D. S. (2004). Sinergetika i informatsiya: Monograph (p. 287). Moscow: URSS.

Drugova, E. A. (2013). Sotsiogumanitarnye aspekty innovatiki v svete kritiki tekhnogennoi tsivilizatsii. Innovatsii v nauke: Materialy XVI Mezhdunarodnoi zaochnoi nauchno-prakticheskoi konferentsii, 1, 40-46. Novosibirsk, Russian Federation: Siberian Association of Consultants.

Durkheim, E. (1951). Suicide: A Study in Sociology (p. 406). Glencoe, IL: The Free Press.

Haken, H. (2012). Synergetics: An Introduction (p. 408). Berlin; Heidelberg; New York; Tokyo: Springer-Verlag.

Heidegger, M. (1967). What is a Thing? Tr. by W. Barton and V. Deutsch. New York: Harper \& Row.

Husserl, E. (1970). The Crisis of European Sciences and Transcendental Philosophy. Tr. by D. Carr. Evanston: Northwestern University Press.

Husserl, E. (1995). L'Origine de la Géométrie. Traduction et introduction par J (p. 219). Derrida. Paris: Presses Universitaires de France.

Kant, I. (1998). Critique of Pure Reason (p. 124). Tr. and Ed. by P. Guyer \& A. W. Wood. New York: Cambridge University Press. http://dx.doi.org/10.1017/CBO9780511804649

Kapitsa, S. P., Kurdyumov, S. P., \& Malinetsky, G. G. (2003). Sinergetika i prognozy budushchego (p. 290). Moscow: Editorial URSS.

Kondratieff, N. D. (1998). In W. Samuels, N. Makasheva, \& V. Barnett (Ed.), The Works of Nikolai D. Kondratiev (Vol. 4). London: Pickering and Chatto.

Luhmann, N. (1993). Risk: A Sociological Theory. Berlin; New York: Walter de Gruyter, Inc.

Mainzer, K. (2007). Thinking in Complexity. The Computational Dynamics of Matter, Mind, and Mankind (5th ed., p. 482). Berlin, Heidelberg, New York: Springer.

Merton, R. K. (1938). Social Structure and Anomie. American Sociological Review, 3(5), 672-682. http://dx.doi.org/10.2307/2084686

Moiseev, N. N. (1998). Sud'ba tsivilizatsii. Put'Razuma. Moscow: MNEPU.

Sharipov, M. S. (2010). Globalizatsiya i krizis mirovoi tsivilizatsii. Vlast', 6, 120-121.

Sinetskiy, S. B. (2012). Eticheskie problemy innovatsionnoi tsivilizatsii. Bulletin of the South Ural State University, 32, 194-197.

Sklyarova, E. E. (2011). Istoricheskie predposylki formirovaniya "Innovatsionnoi tsivilizatsii”. In S. S. Chernova (Ed.), Sovremennye tendentsii v ekonomike i menedzhmente: novy vzglyad: Materialy XI Mezhdunarodnoi nauchnoi i prakticheskoi konferentsii (Vol. 1, pp. 96-101). Novosibirsk, Russian Federation: Novosibirsk State Technical University.

Sorokin, P. (1964). The Basic Trends of Our Times (p. 208). New Haven: College \& University Press.

Stepin, V. S. (2003). Strategii tsivilizatsionnogo razvitiya i problema tsennostei. Rossiya i sovremenny mir, 1 , 5-18. 
Stepin, V. S. (2005). Theoretical Knowledge (p. 398). Netherlands: Springer Science \& Business Media. http://dx.doi.org/10.1007/1-4020-3046-0

Stepin, V. S. (2007). Sistemnost' ob"ektov nauchnogo poznaniya i tipy ratsional'nosti. Bulletin of the Tomsk State University. Philosophy. Sociology. Politology, 1, 65-76.

Toffler, A. (1970). Future Shock (p. 430). New York: Bantam Books.

Toffler, A. (1980). The Third Wave (p. 560). New York: Bantam Books.

Yanitsky, O. N. (2003). Sotsiologiya riska (p. 191). Moscow: LVS.

\section{Copyrights}

Copyright for this article is retained by the author(s), with first publication rights granted to the journal.

This is an open-access article distributed under the terms and conditions of the Creative Commons Attribution license (http://creativecommons.org/licenses/by/3.0/). 